\title{
JUHISTE ESITAMINE HALDUSAKTIDES
}

\section{Riina Reinsalu}

Ülevaade. Kohalikud omavalitsused korraldavad haldusaktide kaudu enda, muude ametkondade, ettevõtete, eraisikute jt tegevust. Et haldusakt täidaks oma eesmärki võimalikult hästi, tuleb valida sobiv tekstistrateegia, mis hõlmab nii struktuuri- kui ka keelevalikuid. Keelekasutaja ei ole valikute tegemisel kunagi päris vaba, vaid ta lähtub suuremal või vähemal määral varasemate tekstide eeskujust ehk žanri- ja laiemalt kultuuritavadest. Artikli valimi moodustavad 75 korraldust, otsust ja käskkirja, mille uurimine žanrianalüüsi meetodil võimaldab välja selgitada nende tekstiliikide ühis- ja erijooned, sealhulgas tekstistrateegilised võtted, mida kasutatakse kommunikatiivse eesmärgi saavutamiseks. Tekstistrateegia hõlmab tekstitüübi valikut: kuna nii korralduse, otsuse kui ka käsu eesmärk on tegu (keegi peab midagi tegema), esindavad need tekstid makrotasandil instruktiivset tekstitüüpi, mikrotasand pakub aga mitme tekstitüübi põimingut. Juhiste esitamise viis on kõigi vaatlusaluste haldusaktide puhul standardne ning tekstiliikide vahel märkimisväärseid struktuurilisi ja keelelisi erinevusi ei esine.

Võtmesõnad: tekstitüüp, tekstiliik, žanr, haldustekst, eesti keel

\section{Sissejuhatus}

Haldusaktideks nimetatakse haldusotsuseid, millega haldusorgan lahendab tekkinud küsimusi (Aedmaa jt 2004: 247). Haldusakti sisu- ja vorminõuded on kehtestatud haldusmenetluse seaduse (HMS) ja kohaliku omavalitsuse korralduse seadusega (KOKS), mis kujundavad haldusakti kontekstuaalse raamistiku. Seadusega etteantud raamistik on oma olemuselt jäik, seades tekstile sisu-ja vormipiiranguid, kuid sisuosa sõnastamisel säilib autoril mõningane valikuvabadus: ta saabjuhinduda piirkondlikest, nt vallavalitsuse tavadest, ja mõnel juhul ka isiklikest eelistustest, eeldusel et need on kooskõlas õigus- ja halduskeele normidega. 
Siinses artiklis võtan vaatluse alla korralduse, otsuse ja käskkirja. Nimetuste poolest esindavad need haldusaktid eri tekstiliike ehk žanre. ${ }^{1}$ Eristus põhineb seaduslikul alusel, millega määratakse kindlaks akti väljaandja, tema pädevusala ja akti väljaandmise tingimused. Seega on osa tekstiliigi erijoontest seotud keeleväliste teguritega, kuid peale sisu kujundavad tekstiliigi olemust ka autori keelelised valikud, mis hõlmavad nii struktuuri, tekstimustreid (korduvaid elemente) kui ka sõnastust - laiemalt kogu tekstistrateegiat, sh tekstitüüpe.

Artikli eesmärk on välja selgitada, millised on vaatlusaluste haldusaktide keelelised ühis- ja erijooned ning kas eri nimetustega akte on põhjust ka keeleliste tunnuste alusel eri tekstiliikideks pidada või lähtub tekstiliikide eristus pelgalt keelevälistest teguritest. Selleks analüüsin esmalt võrdlevalt haldusaktide üldstruktuuri. Kuna korraldused, otsused ja käskkirjad sisaldavad seadustega kindlaksmääratud osi ning põhinevad mitmesugustel eeskujutekstidel, võib eeldada, et nende ülesehitus on üsna standardne. See eeldus põhineb ka teiste tekstiliikide struktuurianalüüsil (vt nt Mandra 2009, Reinsalu 2011). Seejärel keskendun lauseehitusele ja selle kaudu tekstistrateegiale. Mikrotasandil (lause või lõigu piires) hõlmab tekstistrateegia keelelisi valikuid, millest makrotasandil (tervikteksti piires) moodustub instruktiivset tekstitüüpi esindav tekst. Juhiste jagamise viisis väljendub vaatlusaluste haldusaktide žanriline eripära.

Haldusmenetluse seaduse (HMS) kohaselt peab haldusakt olema selge ja üheselt mõistetav, niisamuti seatakse ametliku keelekasutuse ühtlus ja selgus sihiks eesti kirjakeele normi rakendamise korraga (EKNRK). Selgust ja ühemõttelisust taotlevad struktuuri- ja sõnastusvalikud loovad hea aluse suhtluseks, mis põhineb vastastikusel mõistmisel. Seevastu keeleline ähmasus, mis tuleneb näiteks sisutühjadest verbidest, nominalisatsioonidest, pikkadest täiendfraasidest ning keerulisest lauseehitusest, toidab ebavõrdsust. Vajadus tagada haldusaktides peale sisulise täpsuse ka keeleline täpsus annab artiklile rakendusliku väljundi, võimaldades edasistes uurimustes jagada soovitusi haldusaktide selgemaks sõnastamiseks.

\section{Tekstitüübiteooriat}

Tekstitüüp on abstraktne kategooria, mille abil liigitatakse universaalseid, kultuurist ja situatsioonist sõltumatuid keelelisi põhitegevusi (Kasik 2007: 41). Kuna tekstitüübi mõiste on mitmetahuline ja keelelisi põhitegevusi mõistetakse erinevalt, puudub ühtne liigitusalus, mistõttu ei saa rääkida kindlast tekstitüüpide hulgast. Küll aga on paljudes käsitlustes eristatud deskriptiivset, narratiivset ja argumenteerivat tekstitüüpi, mida võib pidada klassikalisteks tekstitüüpideks, kuid eeltoodud kolmikuga liigitus sageli ei piirdu. Näiteks täiendavad Robert de Beaugrande ja Wolfgang Dressler (1981: 184-186) seda loetelu kirjandusliku, poeetilise, teadusliku ja didaktilise tekstitüübiga.

Üks tuntumaid tekstitüübiliigitusi pärineb 1970-ndate teisest poolest Egon Werlichilt. Lähtudes teksti kontekstuaalsest põhieesmärgist, eristab Werlich (1983: 39-41) deskriptiivset, narratiivset, ekspositoorset, argumenteerivat ja instruktiivset tekstitüüpi. Siinse artikli seisukohalt pakub huvi eelkõige instruktiivne tekstitüüp. Werlichi käsitluse kohaselt võib instruktsioonidel ehk juhistel olla kas subjektiivne 
või objektiivne alus. Subjektiivset vaatenurka esindavad näiteks juhtkirjades, jutlustes, ärikirjades, reklaamides esitatavad juhised, mille mõjuvõim tuleneb töösuhetest, staatusest, kogemustest või teadmistest. Objektiivne vaatenurk avaldub aga tööjuhendites, retseptides, kasutusjuhendites jms tekstides, millest juhindumine toob adressaadile praktilist kasu, ning mängureeglites, lepingutes, testamentides jms tekstides, mida on juriidilistel, moraalsetel või õigluslikel kaalutlustel kohustuslik järgida. (Werlich 1983: 121-132)

Egon Werlichi käsitlust on edasi arendanud Basil Hatim ja Ian Mason. Ka nende tekstitüübiliigitus on üles ehitatud teksti kontekstuaalsele eesmärgile, kuid viie tekstitüübi asemel eristavad nemad kolme tekstitüüpi - argumenteerivat, ekspositoorset ja instruktiivset -, seejuures on nad deskriptiivsed ja narratiivsed tekstid paigutanud ekspositoorse tekstitüübi alla (Hatim, Mason 1997: 153-154). Nii nagu Werlich, peavad ka Hatim ja Mason instruktiivse tekstitüübi kontekstuaalseks eesmärgiks mõjutada inimeste mõtlemist ja tegevust. Olenevalt tekstist kasutatakse selleks kas valikuga või valikuta instruktsioone (instructions with/without options). Kui valikuga instruktsioonide (nt reklaamide) puhul tahetakse lugejat kaude tegutsema panna ning lugeja saab otsustada, kas ta järgib juhiseid või mitte, siis valikuta instruktsioonid (nt lepingutingimused) ei jäta lugejale valikuvõimalust, st juhiste järgimine on kohustuslik. (Hatim, Mason 1997: 154-158) Selline valikuga ja valikuta instruktsioonide käsitlus vastab üldjoontes Werlichi subjektiivsele ja objektiivsele vaatenurgale instruktsioonide eristamisel. Käsitlusviiside erinevus tuleb esile tekstide valdkondlikust võrdlusest: Hatim ja Mason nimetavad valikuta instruktsioone sisaldavate tekstidena ainult õigus- ja haldustekste, seevastu Werlichi käsitluses on valdkondlik pilt mitmekesisem.

Tekstitüüpide eristamine ei ole keeruline üksnes teoreetilises plaanis, vaid ka praktikas, sest harilikult sisaldavad tekstid mitme tekstitüübi tunnuseid. Tekstid on oma olemuselt hübriidsed (Hatim, Mason 1997: 147). Nii võib reisikirjeldus olla puhtnarratiivne või hõlmata ka olustikukirjeldusi (deskriptiivne tekstitüüp) või soovitusi (instruktiivne tekstitüüp). Niisamuti leidub tekste, mis keeleliste tunnusjoonte poolest sarnanevad ühe tekstitüübiga, kuid abstraktsemal tasandil teenivad mõne teise tekstitüübi eesmärke. Näiteks on lepingutes palju selliseid lauseid, mis kirjeldavad, mida keegi teeb (nt Töövõtja kasutab tööde tegemisel oma töövahendeid), kuid kontekstuaalsest vaatepunktist on nende tähendus direktiivne ning abstraktsemal tasandil esindavad sellised laused ja ka lepingud tervikuna instruktiivset tekstitüüpi. Anna Trosborg (1997: 16-17) soovitabki käsitleda tekstitüüpe kahetasandilisena: makrotasandil avaldub teksti üldine kommunikatiivne eesmärk ja mikrotasandil tekstistrateegia.

Peale sisuliste erinevuste on lahknevusi ka terminikasutuses. Inglise keeles märgitakse klassikalisi tekstitüüpe terminiga text type, seevastu type of text viitab üldisemalt tekstide tüübile või laadile. Eesti keeles, muu hulgas kooliõpikutes (vt nt Kasik 2007, Kern, Võik 2014), on terminina juurdunud tekstitüüp, kuid teaduskirjanduses on kasutatud ka terminit teksti laad (Meier 2002: 105), mis osutab žanriülestele kvalitatiivsetele erijoontele (Kerge jt 2008: 55). Välise sarnasuse tõttu aetakse tekstitüüp vahel segamini terminiga tekstilïk (ingl genre), mis märgib kultuurisidusat keelekasutust, kuid tunduvalt sagedamini on arusaamatused sisulist laadi, tingituna nende tähendusväljade (osalisest) kattuvusest. 


\section{Tekstitüüpide ja -liikide seosed}

Nii tekstitüüp kui ka tekstiliik kujutavad endast eesmärgipärast keelekasutusviisi. Tekstitüüp kategooriana ei sõltu kultuurist ega situatsioonist, vaid väljendab universaalseid keelelisi põhitegevusi (Kasik 2007: 41). Põhitegevustest tulenevate üldiste eesmärkide raames saab aga eristada mitmesuguseid konkreetsemaid suhtluseesmärke, mille täitmiseks on aja jooksul välja kujunenud kindlad tavad. Need tavad on tihedalt seotud kultuurikontekstiga (kultuurisidusus ongi peamine tegur, mille poolest eristub tekstitüüp tekstiliigist) ning need mõjutavad nii tekstide struktuuri kui ka keelekasutust. Kontekstist oleneb ka tekstiliigi eesmärk, mida peetakse teksti sisemise ülesehituse nurgakiviks. Nii näiteks on John Swales (1990: 58) lähtunud oma žanrimääratluse loomisel just teksti kommunikatiivsest eesmärgist, mis kujundab teksti skemaatilist ülesehitust ning mõjutab sisu- ja keelevalikuid.

Et tekst täidaks oma eesmärki võimalikult hästi, peab autor valima sobiva strateegia, võttes arvesse kultuuritavasid. Seetõttu võib üht ja sama tekstiliiki esindav tekst täita kultuuriti mõnevõrra erinevaid eesmärke või võidakse eesmärgi saavutamiseks kasutada eri strateegiaid. Näiteks ilmneb Saksa ja USA lepingute võrdlusest, et saksakeelsed lepingud on tunduvalt lühemad kui ingliskeelsed. Selle taga on USA lepingute koostajate usaldamatus sealse õigussüsteemi vastu: soovist vältida sisulisi puudujääke ja võimalust neid kurjasti ära kasutada pannakse lepingutingimused kirja võimalikult täpselt, kuid see kasvatab lepingu mahtu märkimisväärselt (Hill, King 2004: 923). Sisu- ja keeletasandil väljenduvaid kultuurierinevusi tuleb arvesse võtta nii tõlkimisel kui ka võõrkeele õppimisel (Schäffner 2000: 215).

Kuigi kultuurisidusus ja eesmärgipärasus on üldiselt aktsepteeritud kriteeriumid, millest lähtutakse žanri määratlemisel, käsitletakse uurimustes žanri mõistet siiski avaralt. Nii eristab Norman Fairclough (2003: 68) kolme tüüpi žanre - eelžanre, üldžanre ja olukohaseid žanre -, millest eelžanrid kuuluvad kõige kõrgemale abstraktsustasandile, hõlmates narratiivi, argumenti, kirjeldust, samuti vestlust. Eelžanri mõistest juhindub ka Swales (1990: 58-61), leides, et vestlus ja narratiiv on verbaalse tegevuse olemuslikud vormid, mis paiknevad justkui väljaspool tavapäraseid žanripiire. Selline mitmetasandiline žanrikäsitlus ähmastab žanri ja tekstitüübi piiri, mistõttu lähtun siinses artiklis mõlema mõiste puhul klassikalisest, seega lihtsustatud käsitlusest, liigitades narratiivi, argumendi ja kirjelduse tekstitüüpidega seotud kategooriateks ning vestluse žanriks, seejuures võib vestlus sisaldada nii jutustavaid, põhjendavaid kui ka kirjeldavaid osi. Vestlus žanrina kuulub üldžanrite tasandile, avaldudes olukohaste žanrite, nt töö- või arenguvestluse kujul. Krista Kerge (2012: 588) käsitleb üldžanri kui üldistust, mis põhineb tekstide sarnasel funktsioonil ja kompositsioonil, seevastu olukohane žanr on kultuuriilming, mis avaldub tegelikes tekstides. Üldžanri tasand võimaldab tulemusi üldistada ja rakendada, kuid see, kuidas keel toimib oma tavapärastes raamides, ilmneb olukohaste žanrite analüüsist (Puksand, Kerge 2012: 170).

Järgnevalt uurin žanrianalüüsi meetodil haldusaktide kui üldžanrite ülesehitust ja tekstimustreid. Haldusakte esindavad siinses artiklis olukohaste žanritena korraldused, otsused ja käskkirjad, mida annavad välja haldusorganid, et reguleerida haldusülesannete täitmist avalik-õiguslikus suhtes (HMS): korraldustega kehtestatakse haldusorgani sees või väljaspool seda mitmesuguseid kohustusi või keelde, otsustega määratakse kindlaks asjaolusid ja käskkirjadega reguleeritakse 
haldusorgani sisemist tööd (KOKS). Et haldusaktid täidaksid oma eesmärki võimalikult hästi, kasutatakse väljakujunenud tekstistrateegiat, mis hõlmab nii tekstitüüpide valikut kui ka žanritavade järgimist.

\section{Materjal ja meetod}

Artikli uurimismaterjali moodustavad korraldused, otsused ja käskkirjad, mis pärinevad kohalike omavalitsuste avalikest dokumendiregistritest. Analüüsitava materjali valisin nende kohalike omavalitsuste dokumentide hulgast, kes kasutavad dokumendihaldustarkvara Amphora KOV. See tarkvara võimaldab dokumente kuvada teemade kaupa ja annab seega hea ülevaate sellest, kas esindatud on kõik vaatlusalused haldusaktid, kas neil puudub seadusest tulenev ligipääsupiirang ja kas need on esitatud sobivas failivormingus (PDF, DOC, DOCX). Analüüsitavad tekstid pärinevad 2013. või 2014. aastast. Nendele valikukriteeriumidele vastasid Audru, Kanepi, Otepää, Paikuse ja Urvaste vallavalitsuse dokumendiregistrid ning nendes esitatud dokumendid. Igalt vallavalitsuselt kaasasin valimisse viis korraldust, otsust ja käskkirja, mis olid 1. novembri 2014. aasta seisuga ajaliselt kõige hilisemad. Seega koosneb valim 75 haldusaktist: 25 korraldusest, 25 otsusest ja 25 käskkirjast.

Allikmaterjali analüüsimisel lähtun Inger Askehave ja John Swalesi (2001) žanrianalüüsi meetodist, mis hõlmab nii teksti struktuuri, keelekasutuse kui ka sisu analüüsi. Tulemuste käsitlemine kontekstis võimaldab jõuda teksti eesmärgini ja seeläbi žanri olemuseni. Järgnevalt annan ülevaate haldusaktide üldstruktuurist, seejärel keskendun tekstistrateegiale, mis hõlmab ka tekstitüübi valikut. Tulemused esitan võrdlevalt, sest žanritunnused tulevad kõige selgemini esile just eri liiki tekstide kõrvutamisel.

\section{Analüüs}

\section{1. Üldstruktuur}

Korraldused, otsused ja käskkirjad on standardse struktuuriga (vt lisad 1-3). Haldusakti päises on esitatud viide akti väljaandjale: korraldusi annavad välja vallavalitsused, otsuseid vallavolikogud ja käskkirju vallavanemad. Kuna vallavalitsuse ja -volikogu nimi sisaldub vastavalt kas korralduse või otsuse päises, piirdutakse akti liigi nimetamisel üksnes sõnadega korraldus ja otsus. Seevastu käskkirjades paikneb viide vallavanemale eri kohtades: päises, pealkirjas (vallavanema käskkiri) ja akti alaosas (allkirjastaja ametinimetus). Vormistuse varieeruvus nii vallavalitsuste vahel kui ka sees näitab, et osutus vallavanemale kujutab endast lisateavet, mille esitamiseks ei ole käskkirja struktuuris välja kujunenud standardseid keelevahendeid.

Peale liigi peab haldusakt seadustest tulenevatel põhjustel sisaldama ka väljaandmisaega ja -kohta. Kõigis vaatlusalustes haldusaktides (v.a kahes otsuses) on osutatud akti väljaandmise kohale. Kohanimi on nimetavas käändes, erandi moodustab üks käskkiri, kus on kasutatud seesütlevat käänet. Osutus ajale paikneb samal real paremal ja sellele on lisatud akti number. Vormistuserinevused tekstiliikide vahel puuduvad, mõningane varieeruvus tuleneb eksimustest õigekirjareeglite vastu (nt O2.oktoober 2014, 21 mai 2014). 
Kõik vaatlusalused haldusaktid sisaldavad kohustusliku vormielemendina pealkirja. Pealkiri on vormiliselt nimisõnafraas, millega väljendatakse haldusakti kui instruktiivse teksti eesmärgiks olevat tegu (nt Hanke korraldamine, Juhatuse liikmete nimetamine, Ehitusloa väljastamine). 74 haldusaktis on mine-vormis teonimi pealkirja põhisõnaks. Vaid ühes korralduses on pealkiri vormistatud kaassõnafraasina (Ostueesõigusega erastamise võimalikkuse kohta), mis kuulub akti nimetuse korraldus juurde, ning tegevus on esitatud modaliseeritult: teo asemel on osutatud teo võimalikkusele. Tekstiliikide võrdlusest ilmneb, et käskkirjade pealkirjad on lühemad, peamiselt kahesõnalised, seevastu korralduste ja otsuste pealkirjad sisaldavad rohkem täpsustavat teavet, koosnedes mõnikord mitmest mine-tarindist (nt Nõusoleku andmine väikeehitise ehitamiseks). Kuna mine-tuletised väljendavad tegevust, on need kooskõlas haldusakti olemusega, sest haldusakti eesmärk on tegu (keegi peab midagi tegema). Samuti viitab sõna akt toimingule, teole.

Pealkirjale järgneb sisuosa, mille tekstimuster kujuneb taustteabest, resolutiivosast ja tingimustest. Taustteave jaguneb kaheks: laiema taustteabe korral selgitatakse põhjalikumalt haldusakti väljaandmise tagamaid, seevastu kitsam taustteave piirdub üksnes viitega õigusaktidele jms. Resolutiivosa, milles avaldub akti regulatiivne toime, st sisuline otsustus (Saaremets 2014: 34), annab edasi haldusakti sisu - tegu, mis tehakse akti jõustumise tulemusena. Resolutiivosa sõnastusest ilmneb rakendatav tekstistrateegia, sh tekstitüübi valik. Sisuosa lõpus esitatakse tingimused akti jõustumise aja ja vaidlustamise võimaluste kohta.

Nii nagu haldusaktide algus, sisaldab ka lõpuosa viidet väljaandjale: akti lõpuosas on esitatud akti allkirjastaja nimi ja ametinimetus. Selline esitusviis tugevdab akti väljaandja ehk teksti adressandi positsiooni võrreldes akti täitjaga ehk teksti adressaadiga, kelle isik peaks selguma akti sisuosast. Teksti adressandi tähtsust rõhutavad osas aktides ka vallavalitsuse/vallavolikogu pitser ning vallavalitsuse vapp kujunduselemendina.

Eeltoodust ilmneb, et haldusaktide üldstruktuur on üsna tavakohastatud. Struktuuriline varieeruvus puudutab vaid üksikjuhte, haldusaktiliikide ja valdade vahel suuri erinevusi ei ilmne. Korralduste, otsuste ja käskkirjade tekstiliigitunnused avalduvad nende sisuosas.

\subsection{Sisuosa}

\subsubsection{Taustteave}

Taustteave kuulub haldusaktide sisuossa, paiknedes vahetult pealkirja all. Erandiks on üks Audru vallavanema käskkiri, kus õiguslik alus (viited otsustele ja määrustele) on paigutatud resolutiivosa järele. See käskkiri erineb teistest Audru vallavanema käskkirjadest ka selle poolest, et seal ei ole nimetatud käskkirja vaidlustamise ja jõustumise tingimusi. Küll aga sisaldab see käskkiri käsitsi kirjutatud pealdist Kätte saanud 20.10.2013, mis osutab, et koondatud vallasekretärile on käskkirja sisu teatavaks tehtud. Ülejäänud haldusaktides on taustteave paigutatud pealkirja alla, nii et see moodustab resolutiivosa sissejuhatuse.

Taustteave täidab haldusaktides kahetist ülesannet. Esiteks pakub see infot haldusakti väljaandmise põhjuste kohta, teiseks aitab see tagada 
vastavust õigusaktidest vms tulenevatele nõuetele. Tabelis 1 on esitatud haldusaktide jagunemine taustteabe järgi.

Tabel 1. Haldusaktide jagunemine taustteabe järgi

\begin{tabular}{|l|c|c|c|}
\hline Haldusakt & Põhjendus & Õiguslik alus & Põhjendus ja õiguslik alus \\
\hline Korraldus & 0 & 17 & 8 \\
\hline Otsus & 0 & 14 & 11 \\
\hline Käskkiri & 1 & 21 & 3 \\
\hline Kokku & 1 & 52 & 22 \\
\hline
\end{tabular}

Tabelist 1 selgub, et 75 haldusaktist 74 sisaldavad viidet õiguslikule alusele, milleks on seadus, määrus, otsus, eeskiri, avaldus, käskkiri, toimik vms kirjalik õigus- või haldustekst. Viidete vormistamiseks kasutatakse enamasti kas tagasõna alusel või mõnd des-lauselühendit (nt võttes aluseks/arvesse, arvestades, lähtudes, juhindudes), harvem sõnu ettepanekul, tulenevalt, vastavalt, seoses. Selline viitamine on iseloomulik kõigile vaatlusalustele tekstiliikidele, kuid erinevused tulevad esile esitatud viidete hulgas. Nimelt sisaldavad üht-kaht viidet $80 \%$ käskkirjadest, $60 \%$ otsustest ja vaid $40 \%$ korraldustest. Korralduste taustteabes on esitatud enamasti vähemalt kolm viidet, kuid näiteid leidub ka kaheksa ja kümne viitega korralduste kohta (näites 1 on viidatud ühele seadusele ja seitsmele määrusele) ${ }^{2}$. Viidete rohkus tugevdab teksti adressandi positsiooni, sest näitab, et tema tegevusel on kindel õiguslik alus.

(1) Võttes aluseks sotsiaalhoolekande seaduse, Kanepi Vallavolikogu 17.02.2005. a määruse $n r$, volikogu 15.02.2007. a määruse $n r$, volikogu 24.04.2008. a määruse nr 14 ja volikogu 18.02.2010. a määruse nr 7; Kanepi Vallavolikogu 14.09.2006. aasta määruse $\mathrm{nr} 26$; volikogu 17.02.2009. a määruse nr 4 ja Kanepi Vallavolikogu 21.02.2013 määruse nr 7 annab Kanepi Vallavalitsus korralduse:

1. Maksta sotsiaaltoetusi oktoobri kuul alljärgnevalt: ...

Nende 74 haldusakti hulgas on 22 akti, mis sisaldavad peale õigusliku aluse ka laiemat taustteavet ehk akti väljaandmise põhjendust. Kui õiguslikule alusele viidatakse alati sisestatud tarindiga põhilause sees, siis individuaalsed põhjendused esitatakse eraldi tekstiosana. Need põhjendused on eri pikkusega, varieerudes ühest lausest ühe leheküljeni, seejuures võib põhjendus olla vormistatud eraldi lõiguna ja/või ühendatud viitega õigusaktidele. Nii on näites (2) esitatud esmalt laiem taustteave (põhjendus), mis kujutab endast refereeringut isiku avaldusest, seejärel on see seotud sõna eelnevast abil lõiguga, mis sisaldab viidet seadusele ja avaldusele. Taustteave esindab deskriptiivset tekstitüüpi, kuid võib sisaldada ka narratiivse tekstitüübi tunnuseid (tegevus antakse edasi ajalises järjekorras).

(2) Paikuse Vallavalitsuse sotsiaaltöö spetsialist NN esitas 26.09.2014 avalduse kanda üle oma ajakavas 6. oktoobril algama pidava puhkuse 2015. aastasse. Selgitab, et ta vajab puhkepäevi 2015. aastal Tallinna Ülikooli lõpetamiseks vajaliku magistritöö kirjutamise ja kaitsmise ettevalmistamisega.

2 Kõik siinse artikli näited on esitatud sellisel kujul, nagu need vaatlusalustes haldusaktides esinevad. Muudetud 
Abivallavanem MM toetab sooviavaldust.

Eelnevast ja Töölepingu seadusest $§ 69 \lg 4$ tulenevalt ning võttes aluseks $\mathrm{N}-\mathrm{i}$ avalduse

1. Teha muudatused 26. märtsi 2014 käskkirja nr 4-P kinnitatud puhkuste ajakavas ja lubada sotsiaaltöö spetsialisti NN-i osaline puhkus 2014. aasta eest 7 kalendripäeva ulatuses kanda üle 2015. aastasse.

Korralduste, otsuste ja käskkirjade analüüsist selgub, et viited õigusaktidele on taustteabena obligatoorsed, individuaalsed põhjendused lisateabena aga fakultatiivsed. Taustteabe esitamine piisavas mahus annab teksti adressandile vaide korral suurema kindlustunde. Põhjus, miks käskkirjades piirdutakse peaasjalikult vaid paari viitega õigusaktidele ja üksikasjalikke põhjendusi ei esitata, võib seisneda selles, et käskkirju ei kiputa vaidlustama, mistõttu pole vallavanemal vaja kindlustada oma seljatagust põhjaliku taustteabega. Seda toetab ka fakt, et paljudes käskkirjades pole vaidlustamistingimusi esitatud.

\subsubsection{Resolutiivosa}

Taustteabele järgneb resolutiivosa, mis annab edasi akti põhisisu. 48 haldusaktis on resolutiivosa taustteabega süntaktiliselt seotud, kuid 27-s mitte (vt eespool näited 1 ja 2). Täpsemad andmed aktide liikide kaupa on esitatud tabelis 2. Analüüs näitab, et haldusorganitel on välja kujunenud kindlad tavad, kuidas üht või teist haldusakti vormistada. Erandi moodustavad Audru vallavalitsuse korraldused, millest kolmes on süntaktiline seos taustteabe ja resolutiivosa vahel olemas, kahes aga mitte. Samuti ilmneb analüüsist tendents vormistada ühe haldusorgani piires kõiki kolme haldusakti ühtmoodi. Seda joont ei ole hoitud vaid Audru ja Urvaste käskkirjades, mille taustteave ja resolutiivosa on vormistatud teisiti kui nende korralduste ja otsuste oma.

Tabel 2. Haldusaktide jagunemine resolutiivosa ja taustteabe seotuse järgi

\begin{tabular}{|l|c|c|}
\hline Haldusakt & Taustaga sidumata & Taustaga seotud \\
\hline Korraldus & 7 & 18 \\
\hline Otsus & 5 & 20 \\
\hline Käskkiri & 15 & 10 \\
\hline Kokku & 27 & 48 \\
\hline
\end{tabular}

Kõigis vaatlusalustes haldusaktides, mille taustteave on resolutiivosaga süntaktiliselt seotud, on antud juhislausele deklaratiivse kõneteo kuju, st korralduse, otsuse või käskkirja väljaandja nimetab omaenda tegevust. Sõnastusviis oleneb haldusaktist: korraldustes ja otsustes kasutatakse oleviku ainsuse kolmandat pööret ning käskkirjades oleviku ainsuse esimest pööret (vt tabel 3). 
Tabel 3. Haldusaktide vormistus taustteabe ja resolutiivosa süntaktilise seotuse korral

\begin{tabular}{|l|c|c|c|c|c|}
\hline Korraldused & Arv & Otsused & Arv & Käskkirjad & Arv \\
\hline X Vallavalitsus annab korralduse & 9 & & & annan käskkirja & 5 \\
\cline { 1 - 2 } X Vallavalitsus korraldab & \multicolumn{2}{|c|}{$\begin{array}{c}\text { X Vallavolikogu } \\
\text { otsustab }\end{array}$} & 20 & käsin & 5 \\
\cline { 1 - 2 } X Vallavalitsus otsustab & 3 & & & \\
\hline X Vallavalitsus annab välja korralduse & 1 & & 20 & & 10 \\
\hline Kokku & 18 & & & & \\
\hline
\end{tabular}

Sõnastuse ühtluse poolest paistavad silma otsused. Kõik 20 otsuslauset on esitatud kujul X Vallavolikogu otsustab, millele järgneb da-infinitiivi vormis direktiivne osa: loetelu sellest, mida plaanitakse teha (3). Nimelt on otsuslauseid verbi otsustab ja $d a$-infinitiivitarindi abil lihtne moodustada, mistõttu puudub vajadus sõnastuse varieerimise järele.

(3) Kohaliku omavalitsuse korralduse seaduse § 22 lõike 2 alusel Urvaste Vallavolikogu

otsustab:

1. Deklareerida Urvaste Vallavalitsusele Maakatastriseaduse § $18 \lg 2,4,5$ ja 6 omavalitsusele omistatud katastriüksuste sihtotstarbe määramise õigus.

Käskkirjades on taustteave ja resolutiivosa seotud kahel viisil: viiel juhul kommenteerib vallavanem oma tegevust sõnadega annan käskkirja, millele järgneb kas oleviku ainsuse esimese pöörde või oleviku ainsuse esimese pöörde ja $d a$-infinitiivi vormis loetelu (4), ning viiel juhul sõnaga $k a ̈ s i n$, millele järgneb üksnes da-infinitiivi vormis loetelu (5). Kuna annan käskkirja loob süntaktilise väärseose, kui seda kasutada koos $d a$-infinitiivitarindiga, ja käsin mõjub rangelt, pealegi ka sobimatuna, kui käskkiri on nt puhkusele lubamise kohta, otsivad käskkirja väljaandjad muid sõnastusviise. See võib olla põhjus, miks käskkirjades piirdutakse teistest juhistekstidest sagedamini üksnes $d a$-infinitiivi vormis loeteluga, mis ei ole taustteabega süntaktiliselt seotud (vt eespool näide 2).

(4) Vabariigi Valitsuse 25.06.2009 määruse nr 110 „Töölähetuse kulude hüvitiste maksmise kord ning välislähetuse päevaraha alammäär, maksmise tingimused ja kord” paragrahvi 2 alusel annan käskkirja:

1. Lähetan ajavahemikul 12.08-14.08.2014 Viljandimaal Kopra talus toimuvatele õppepäevadele VIII Üleriigiline Rahvamajade suvekool Kanepi Seltsimaja juhataja NN-i.

2. Hüvitada lähetuskulud esitatud kuludokumentide alusel.

...

(5) Kohaliku omavalitsuse korralduse seaduse $\S 50$ lõike 1 punkti 3 ja töölepingu seaduse $\S 69$ lõike 4 alusel, käsin:

1. Muuta vallavanema 27.03.2014. a käskkirjaga nr 9.1-1.2-51 "Puhkuste ajakava kinnitamine" kinnitatud puhkuste ajakava punkti 14 ja tunnistada ajavahemik 14.11.- 28.11.2014.a sotsiaaltööspetsialist NN-i osas kehtetuks. 
2. Anda sotsiaaltööspetsialist NN-ile puhkust ajavahemikul 17.11.24.11.2014.a. ( 8 kalendripäeva).

Korralduste puhul on pilt kirjum. Kümnel juhul on deklaratiivne kõnetegu edasi antud nominalisatsiooniga korraldus ( $X$ Vallavalitsus annab korralduse või $X$ Vallavalitsus annab välja korralduse (vt eespool näide 1) ja viiel juhul verbiga korraldama (6), seejuures on verbivormi korraldab ja sellele vahetult järgneva dainfinitiivi kasutamine vaid ühe vallavalitsuse tava. Sellise sõnastusviisi vähest levikut saab põhjendada tekkiva rektsiooniveaga (korraldab mida, mitte korraldab mida teha). Kolmes korralduses on aga kasutatud verbi otsustama (7). Need korraldused meenutavad oma sõnastuselt otsuseid, sest otsuslause ( $X$ otsustab midagi teha) on iseloomulik just otsustele, ning hägustavad tekstiliikide piire.

(6) Võttes aluseks kohaliku omavalitsuse korralduse seaduse § 30 lõike 1 punkti 2, Otepää valla vallavara eeskirja § 36 lõike 3 ja Pühajärve Põhikooli poolt 13. oktoobril 2014. a koostatud vara mahakandmise akti, Otepää Vallavalitsus korraldab:

1. Kanda Pühajärve Põhikoolis maha 838 ühikut kasutusele võetud töövihikuid, kokku summas 3 132,22 eurot. $\cdots$

(7) Ehitusseaduse $\S 16 \lg 1$ p 1, Urvaste Vallavolikogu 18.05.2004.a. määruse nr 1-1/7 „Urvaste valla planeerimis-ja ehitusmäärus“ IX p-de 1, 2, 7 ja 11 ning NN-i 17.10.2014 taotluse alusel, Urvaste Vallavalitsus

\section{otsustab:}

1. Väljastada NN-ile kirjalik nõusolek väikeehitiste (puurkaev) rajamiseks Kähri kinnistul (84301:004:1820), Vaabina külas, Urvaste vallas, Võru maakonnas.

$\cdots$

Olenemata sellest, kas resolutiivosa on taustteabega süntaktiliselt seotud või mitte, kasutatakse haldusaktides selle vormistamiseks peamiselt $d a$-infinitiivi, mis on vaatlusaluste tekstide üks keskseid tunnusjooni. Korralduste ja otsuste sisu antakse edasi üksnes $d a$-infinitiivitarindite kujul, seejuures koosneb resolutiivosa keskmiselt kahest $d a$-infinitiivitarindist (korraldustes kuni seitsmest, otsustes kuni kuuest). Niisamuti on käskkirjades ülekaalus da-infinitiivitarindid (15 juhul, vt eespool näide 5), kuid leidub ka selliseid tarindeid, mis on esitatud oleviku ainsuse esimese pöörde vormis (4 juhul, vt näide 8) või milles on oleviku ainsuse esimese pöörde vormi kombineeritud $d a$-infinitiivi vormiga ( 5 juhul, vt eespool näide 4) või umbisikulise tegumoega (1 juhul, vt näide 9). Erinevalt korraldustest ja otsustest annab käskkirju välja ainuisik, mis teeb võimalikuks oleviku ainsuse esimese pöörde kasutamise. Umbisikulise tegumoe vormid liigituvad erandliku keelekasutuse alla.

(8) Võttes aluseks töölepingu seaduse $\S 69$ lõike 4 ning esitatud avalduse annan käskkirja:

1. Luban põhipuhkust 5 kalendripäeva finantsnõunik $\mathrm{NN}$-ile alates 01 . detsember kuni 05. detsember 2014. 
(9) Töölepingu seaduse § 21 lõike 1, Audru Vallavolikogu 10.10.2013 määruse nr 26 „Audru valla põhimääruse kinnitamine“ $§ 48$ lõike 2 punkti 7, Audru Vallavanema 24.04.2014 käskkirja nr 21.1-1.5/13 kinnitatud „Audru Vallavalitsuse töökorralduse reeglid“ punkti 6 ning NN-i 27.10.2014 avalduse alusel:

1. Saadan Aruvälja Raamatukogu juhataja NN-i siselähetusse 30. oktoobril 2014 Paide Kultuurikeskuses toimuvale XIV raamatukoguhoidjate päevale.

2. Lähetatule hüvitatakse sõidukulud lähetuse kulude aruande ja kuludokumentide alusel õigusaktides sätestatud korras. ...

Eeltoodust ilmneb, et akti väljaandja ehk tegevuse adressant on kas akti pealkirjas või taustteavet ja resolutiivosa siduvas lauseosas eksplitsiitselt väljendatud ning seega selgel jõupositsioonil: tema annab korralduse, otsustab või käsib midagi teha. Niisamuti on fookuses tegu, mis moodustab akti resolutiivosa ja on eraldi punktidena välja toodud. Ent enamikus vaatlusalustes haldusaktides pole mainitud tegevuse adressaati ehk korralduse, otsuse või käsu elluviijat. Vaid kolm korralduste $d a$-infinitiivitarindit sisaldab otsest viidet tegijale, kelleks on toetuse saaja, ostja ja abivallavanem. Otsustes on tegijat mainitud mõnevõrra sagedamini: da-infinitiiviga väljendatud tegevusi peab kolmel juhul täitma vallavalitsus, kahel juhul vallakantselei ja ühel juhul vallavanem. Tegevuse adressant on alalütleva käände vormis (nt Ametist vabastatud vallavanemal anda asjaajamine ja tema kätte usaldatud vara üle 24.oktoobriks.2014. a). Käskkirjades osutab ainsuse esimese pöörde vorm selgelt vallavanema kui aktiivse osalise rollile, seevastu $d a$-infinitiivi vormis käsud on sõnastatud nii, et tegija nendest ei selgu.

Tegevuse adressaadi puudumist haldusaktides võib seletada sellega, et üks osa $d a$-infinitiiviga väljendatud tegevustest tehakse akti väljaandmise hetkel: korraldus, otsus või käsk ongi tegu, nt toetuse määramine, teenistusse ennistamine, komisjoni moodustamine. Küll aga võib selline $d a$-infinitiivitarind sisaldada muid tarindeid, kus on tegevuse adressaati otsesõnu mainitud. Näiteks lauses Volitada Paikuse Vallavalitsust vallavanem NN'i isikus alla kirjutama otsuse punktis 1 nimetatud taotlusele pole tähtis mitte volitaja, vaid taotlusele alla kirjutaja, kelleks on kaudselt Paikuse vallavalitsus, otseselt aga vallavanem. Teine osa $d a$-infinitiiviga väljendatud tegevustest eeldab küll tegijat, nt sotsiaaltoetuste maksmine, halduslepingu sõlmimine, hanke korraldamine, kuid kuna asutusesisese töökorralduse järgi on teada, kes mida peab tegema, puudub vajadus tegevuse adressaadi nimetamise järele (pealegi muudaks see sõnastuse kohmakaks).

Taustteabe ja resolutiivosa süntaktiline vormistus ning $d a$-infinitiivitarindite kasutus moodustavad osa tekstistrateegiast. Süntaktilise seose puudumisel mõjuvad $d a$-infinitiivitarindid karmi käsuna, esindades nii mikro- kui ka makrotasandil valikuta instruktsioone. Seevastu $d a$-infinitiivitarindite esitamine deklaratiivse kõneteo koosseisus pehmendab teo tegemise nõuet: juhendamise asemel kirjeldatakse primaarselt iseenda tegevust ja instruktsioonid esitatakse vahendatult. Nii mõjub konstruktsioon $X$ Vallavolikogu/Vallavalitsus otsustab $+d a$-infinitiiv neutraalse kirjeldusena, kuid $X$ Vallavalitsus annab korralduse $+d a$-infinitiiv on mõnevõrra karmim, väljendades nõuet midagi teha. Konstruktsioonid X Vallavalitsus korraldab, X Vallavalitsus annab välja korralduse ja annan käskkirja $+d a$-infinitiiv on vastuolus loomuliku keelekasutusega, mistõttu on nõude, käsu 
vms rangust keeruline määrata. Küll aga esindab otsest käsku verbivorm käsin koos da-infinitiivitarindiga.

Deskriptiivse tekstitüübi osa nii korraldustes, otsustes kui ka käskkirjades suurendavad laused, mis on lisatud juhendavate ehk $d a$-infinitiivi vormis lausete hulka. Nii näiteks algab lisas 2 esitatud otsuse resolutiivosa $d a$-infinitiivitarindit sisaldava loetelupunktiga, seejärel kirjeldatakse teises punktis üksikasjalikult komisjoni pädevusse kuuluvaid toiminguid. Samuti on lisas 3 toodud käskkirjas rakendatud vaheldumisi instruktiivset ja deskriptiivset tekstitüüpi: käskkiri algab käsuga nimetada töötaja ametisse ja määrata kindlaks tema põhipalk, seejärel esitatakse kirjelduse vormis viide avaliku võimu teostamise õiguslikule alusele ja nimetatakse ametikoha asukoht. Sellele järgnevad käsk kohaldada katseaega, töötaja staaži kirjeldus ja käsk kinnitada ametijuhend. Selline esitusviis viib fookuse tegevuselt kõrvale. Et haldusakt täidaks oma eesmärki võimalikult hästi, peaks see piirduma üksnes õiguste ja kohustuste reguleerimisega, mitte sisaldama üleliigseid täpsustusi ja selgitusi (Saaremets 2014: 37).

\subsubsection{Väljaandmise tingimused}

Haldusaktide sisuosa standardelementide hulka kuuluvad andmed akti jõustumise aja ja vaidlustamise võimaluste kohta. Enamikus korraldustes ja otsustes on esitatud mõlemad tingimused, mis näitab, et nii jõustumine kui ka vaidlustamine on akti seisukohalt olulised. Nii nagu käskkirjad erinesid teistest haldusaktidest viidete hulga poolest, erinevad need ka tingimuste esitusviisi poolest: viis käskkirja ei sisalda kumbagi tingimust, 17 käskkirjas piirdutakse üksnes jõustumisajaga ja ühes käskkirjas vaidlustamisvõimalustega.

Mõlema tingimuse sõnastus seab fookusesse teo. Jõustumise tingimus on esitatud enamasti kujul Korraldus/käskkiri/otsus jõustub teatavakstegemisest, seejuures sisaldavad vaid viis korraldust ja üks otsus alaleütlevas käändes viidet osalisele, kellele akt teatavaks tehakse. Niisamuti jääb osaline tagaplaanile sõnastusvariantides Käskkiri jõustub allakirjutamisel, Otsus jõustub vastuvõtmisel ja Käskkirja rakendatakse alates 01. jaanuarist 2013. Osaliste poolest on sama ebamäärane vaidlustamise punkt: see on muude punktidega võrreldes üks pikimaid, hõlmates $3-5$ rida, kuid väljendab ainult vaide esitamise võimalust, mitte osalist (nt Korraldust/käskkirja/otsust on võimalikvaidlustada .., Korralduse/käskkirja/ otsuse peale võib esitada vaide ..). Ka siin on kogu tähelepanu teol. Jõustumise ja vaidlustamise tingimused esindavad deskriptiivset tekstitüüpi.

\section{Kokkuvõte}

Žanrianalüüsi seisukohalt on keelekasutus kombinatsioon universaalsetest ja kultuurispetsiifilistest tunnusjoontest. Universaalsed keelelised tunnusjooned on seotud tekstitüübiga, näiteks on keeles hulk käsu väljendamise viise. See, milline viis valitakse, oleneb aga tekstiliigist ja laiemalt kultuuritavadest. Korralduste, otsuste ja käskkirjade keelekasutust mõjutab seotus õiguse ja halduse valdkonnaga, mis seab väljendusviisile ranged piirangud. 
Vaatlusalused haldusaktid on valdkonnale omaselt standarditud ülesehitusega. Haldusaktide tekstimuster moodustub akti nimetusest, väljaandmiskohast ja -ajast koos akti numbriga, pealkirjast, sisuosast, allkirjastaja nimest ja ametinimetusest. Selline esitusviis koos akti üldise kujundusega toetab akti väljaandja ehk teksti adressandi võimupositsiooni ja seab fookusesse sisuosa.

Sisuosa vormistamisel rakendatakse kahesugust tekstistrateegiat. Enamikus haldusaktides antakse põhisisu edasi deklaratiivselt: akti väljaandja kommenteerib iseenda tegevust (X Vallavalitsus annab korralduse, $X$ Vallavalitsus korraldab, $X$ Vallavalitsus annab välja korralduse, $X$ Vallavolikogu/Vallavalitsus otsustab, annan käskkirja, käsin). Deklaratiivse kõneteo keskmes on resolutiivosa, millega väljendatakse tegu, mis tuleb akti täitjal ehk teksti adressaadil teha. Taustteave lisab resolutiivosaga süntaktiliselt seostatuna akti väljaandja sõnadele kaalukust. Kuigi resolutiivosa on esitatud $d a$-infinitiivitarindite kujul, ei mõju need enamasti rangelt kohustavana, sest lause tervikuna esindab deskriptiivset, mitte instruktiivset tekstitüüpi. Teist laadi on aga need haldusaktid, mille taustteabe ja resolutiivosa vahel puudub süntaktiline seos. Sel juhul annab $d a$-infinitiiv edasi otsest nõuet, mistõttu on resolutiivosa oma vormilt instruktiivne. Seega pakub vaatlusaluste haldusaktide mikrotasand deskriptiivse ja instruktiivse tekstitüübi põimingut. Deskriptiivse tekstitüübi osakaalu suurendab akti väljaandmise põhjuste selgitamine taustteabe osas ja da-infinitiiviga väljendatud tegevuste täpsustamine resolutiivosas. Makrotasandil on vaatlusalused haldusaktid aga instruktiivsed, kujundades esitatavate juhiste kaudu osaliste edasist tegevust.

Korralduste, otsuste ja käskkirjade võrdlus näitab, et üldstruktuurilt on vaatlusalused haldusaktid väga sarnased ning sisuosas (taustteabe ja juhiste esitamises, osaliste nimetamises) esineb vaid väikesi erinevusi. Kui korraldused ja otsused sisaldavad rohkelt viiteid akti väljaandmise põhjustele ja kohalduvatele õigusaktidele, siis käskkirjades piirdutakse enamasti mõne üksiku viitega õigusaktidele ja põhjuseid pole peetud vajalikuks nimetada. Samuti on erinevalt käskkirjadest korraldustes ja otsustes taustteave resolutiivosaga süntaktiliselt seotud. Korralduste ja otsuste resolutiivosa koosneb üksnes $d a$-infinitiivitarinditest, mille vahele on mõnes aktis lisatud ka kirjeldavaid täpsustusi, kuid käskkirjades kasutatakse peale $d a$-infinitiivi ka oleviku ainsuse esimese pöörde vormi, mille korral on tegevuse adressaat esitatud eksplitsiitselt. Seega on korralduste ja otsustega võrreldes käskkirjades rohkem varieeruvust, mida võib seletada sellega, et korraldusi ja otsuseid annab välja kollektiivne isik (vastavalt vallavalitsus ja vallavolikogu), kuid käskkirju üksikisik (vallavanem). See annab rohkem valikuvabadust ka resolutiivosa sõnastamisel. Erinevalt korraldustest ja otsustest, kus resolutiivosa ja taustteavet on keeleliselt lihtne üksteisega siduda (nt X Vallavalitsus annab korralduse, X Vallavolikogu otsustab), on käskkirjade sõnastamine keerulisem, sest konstruktsioon annan käskkirja + da-infiniivitarind on kohmakas, seevastu konstruktsioon käsin (samuti annan käsu) $+d a$-infinitiiv mõjub liiga rangena. (Näiteid korralduste, otsuste ja käskkirjade vormistamise kohta vt Raadik 2008, 2011.)

Kuna korralduse, otsuse ja käskkirja liigitamine eri haldusaktideks põhineb peamiselt keelevälistel (sisulistel) tunnustel, võib neid keelekasutuse, sh tekstimustrite järgi pidada üheks žanriks. Vaadeldud struktuurilised ja keelelised tunnusjooned on iseloomulikud haldusaktile kui üldžanrile, korralduste, otsuste ja käskkirjade kui olukohaste žanrite tasandil suuri erinevusi struktuuris ja keelekasutuses ei esine. 


\section{Viidatud kirjandus}

Aedmaa, Anno; Lopman, Evelin; Parrest, Nele; Pilving, Ivo; Vene, Einar 2004. Haldusmenetluse käsiraamat. Tartu: Tartu Ülikooli Kirjastus.

Askehave, Inger; Swales, John 2001. Genre identification and communicative purpose: A problem and possible solution. - Applied Linguistics, 22 (2), 195-212. http://dx.doi. org/10.1093/applin/22.2.195

Beaugrande, Robert; Dressler, Wolfgang 1981. Introduction to Text Linguistics. London-New York: Longman.

EKNRK = Eesti kirjakeele normi rakendamise kord 2011. Riigi Teataja I, 14.06.2011, 3. https://www.riigiteataja.ee/akt/114062011003 (24.2.2016).

Fairclough, Norman 2003. Analysing Discourse: Textual Analysis for Social Research. London-New York: Routledge.

HMS = Haldusmenetluse seadus 2002. Riigi Teataja I 2001, 58, 354. https://www.riigiteataja. ee/akt/686696 (24.2.2016).

Hatim, Basil; Mason, Ian 1997. Discourse and the Translator. London-New York: Longman.

Hill, Claire; King, Christopher 2004. How do German contracts do as much with fewer words? - Chicago-Kent Law Review, 79 (3), 889-926. http://scholarship.kentlaw. iit.edu/cklawreview/vol79/iss3/23/ (24.2.2016).

Kasik, Reet 2007. Sissejuhatus tekstiõpetusse. Tartu: Tartu Ülikooli Kirjastus.

Kerge, Krista; Pajupuu, Hille; Tamuri, Kairi; Meier, Heidi 2008. Kõnetehnoloogia vajab žanrilist lähenemist. - Eesti Rakenduslingvistika Ühingu aastaraamat, 4, 53-65. http://dx.doi.org/10.5128/ERYa4.04

Kerge, Krista 2012. Let's Talk Linguistics. - Keel ja Kirjandus, 4, 581-597.

Kern, Katrin; Võik, Ilona 2014. Korras keel, sobiv stiil, selge sõnum. Tallinn: Maurus Kirjastus.

KOKS = Kohaliku omavalitsuse korralduse seadus 1993. Riigi Teataja I 1993, 37, 558. https:// www.riigiteataja.ee/akt/126032013006? leiaKehtiv (24.2.2016).

Mandra, Katrin 2009. Haldusteksti struktuurist Tartu linnavalitsuse korralduste näitel. Eesti Rakenduslingvistika Ühingu aastaraamat, 5, 131-141. http://dx.doi.org/10.5128/ ERYa5.08

Meier, Heidi 2002. Olulisi aspekte tekstitüübivõrdluses. - Artikleid tekstianalüüsist. Tekstid ja taustad. Tartu Ülikooli eesti keele õppetooli toimetised 23. Tartu: Tartu Ülikooli kirjastus.

Puksand, Helin; Kerge, Krista 2012. Õpiteksti analüüs kirjaoskuse omandamise kontekstis. Emakeele Seltsi aastaraamat, 57 (2011), 162-217. http://dx.doi.org/10.3176/esa57.09

Raadik, Maire 2008. Kuidas vormistada ametikirja. Tartu: Keelehooldekeskus.

Raadik, Maire 2011. Väikesed tarbetekstid: käsiraamat. Tallinn: Eesti keele Sihtasutus.

Reinsalu, Riina 2011. Leping tekstiliigina: žanristruktuur. - Eesti Rakenduslingvistika Ühingu aastaraamat, 7, 215-229. http://dx.doi.org/10.5128/ERYa7.13

Saaremets, Virgo 2014. Resolutsioon olgu regulatiivne, regulatsioon olgu resoluutne. Õiguskeel, 4, 33-44.

Schäffner, Christina 2000. The role of genre for translation. - A. Trosborg (Eds.), Analysing Professional Genres. Pragmatics and Beyond New Series 74. Amsterdam-Philadelphia: John Benjamins Publishing Company, 209-224.

Swales, John 1990. Genre Analysis: English in Academic and Research Settings. Cambridge: Cambridge University Press.

Trosborg, Anna 1997. Text typology: Register, genre and text type. - A. Trosborg (Ed.), Text Typology and Translation. Amsterdam-Philadelphia: John Benjamins Publishing Company, 3-23. http://dx.doi.org/10.1075/btl.26.03tro

Werlich, Egon 1983. A Text Grammar of English. Heidelberg: Quelle und Meyer.

Riina Reinsalu (Tartu Ülikool) on eesti keele eriala doktorant, kes uurib peamiselt õigus- ja haldustekste. Jakobi 2, 50090 Tartu, Estonia 


\section{Lisa 1. Kanepi vallavalitsuse korraldus}

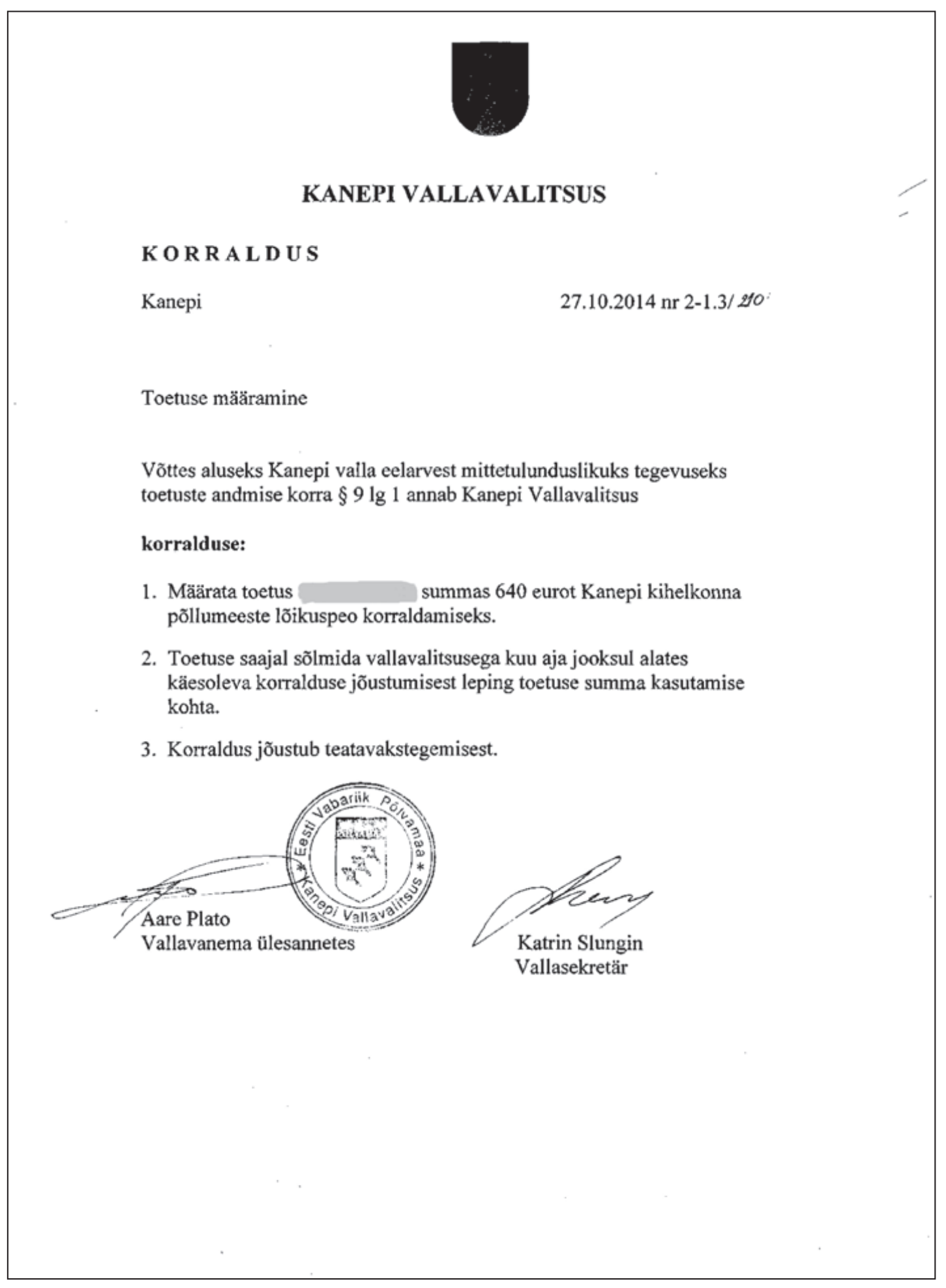




\title{
Lisa 2. Urvaste vallavalitsuse otsus
}

\author{
. \\ VÕRU MAAKOND \\ URVASTE VALLAVOLIKOGU \\ OTSUS
}

Kuldre

21 mai $2014 \mathrm{nr} 14$

Revisjonikomisjoni

volituste laiendamine

Urvaste valla põhimăăruse $\S 37,38$ ja 41, Korruptsioonivastase seaduse $\S 3 \lg 3, \S 13 \lg 1$ p 2 ning $§ 15 \lg 2$ alusel Urvaste Vallavolikogu

\section{OTSUSTAB:}

1. Anda vallavolikogu revisjonikomisjoni pädevusse Urvaste valla avalikku ülesannet täitva ametiisikute (deklarantide) korruptsiooni ennetamise alase teadlikkuse ja kohustustest kinnipidamise kontrolli tagamine, sh

1.1. deklarantide kohta alusandmed esitamine huvide deklaratsioonide registrile ja

1.2. deklarantide poolt esitatud huvide deklaratsioonide kontrollimine.

2. Komisjoni pådevusse kuulub lisaks Urvaste valla põhimääruse $\S 38$ ja 41 sätestatud komisjoni õigustele:

2.1. selgituste nõudmine deklarantidelt ja kolmandalt isikult deklaratsiooni sisu, deklaratsiooni esitamise tähtaja eiramise või deklaratsiooni esitamata jätmise põhjuste kohta; 2.2. esitada päringuid ja saada deklarandi kohta deklaratsiooni kontrollimiseks vajalikus ulatuses andmeid krediidiasutustelt ja riigi või kohaliku omavalitsuse andmekogudest.

2.4. deklaratsiooni kontrollimise tulemusel tekkinud süüteokahtluse korral vallavolikogu esimehe teavitamine. Süüteokahtluse korral esitab volikogu esimees deklaratsiooni kontrollimise materjalid prokuratuurile või kohtuvälisele menetlejale.

2.5. vallavalitsuselt ja allasutuste juhtidelt teabe nõudmine korruptsiooni ennetamise alase teadlikkuse ja kohustustest kinnipidamise kohta, sh tutvuda dokumentatsiooniga.

2.6. komisjoni poolt lăbiviidud kontrolltoimingute protokollimine ja volikogule 1 kord aastas komisjoni tegevuse kohta aruande esitamine.

3. Otsus jõustub teatavakstegemisest.

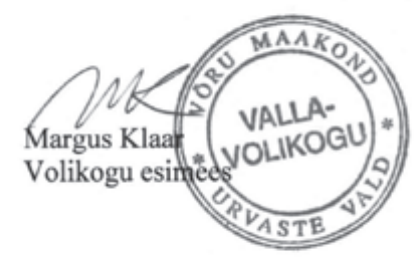




\section{Lisa 3. Otepää vallavalitsuse käskkiri}

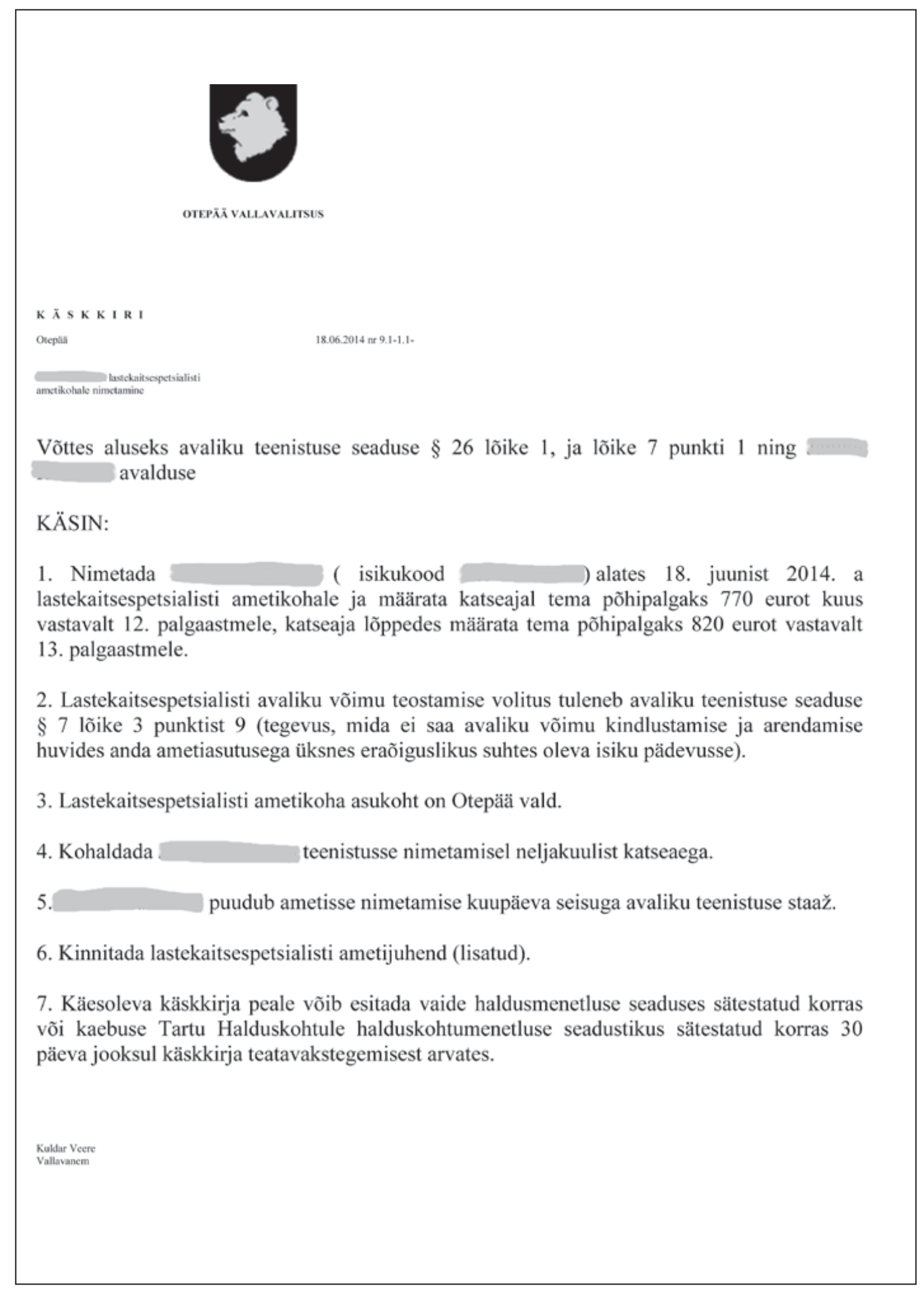




\title{
PRESENTING INSTRUCTIONS \\ IN ADMINISTRATIVE ACTS
}

\author{
Riina Reinsalu
}

University of Tartu

Local governments employ administrative acts for managing their own activities as well as those of other offices, businesses, private persons, etc. In order for an administrative act to best fulfil its purpose, a suitable textual strategy, covering both structural and linguistic choices, must be selected. No language user is entirely free in making such choices, but rather proceeds to a greater or lesser degree from examples set by previous texts, i.e. from conventions of genre and of the wider culture.

The purpose of this paper is to determine what kinds of textual strategies and devices (including text types) are employed in orders, decisions, and directives for the purpose of achieving a genre-specific goal. Since the law specifies the issuer of the act, their sphere of competence, and the conditions for the issuance of the act, it can be presumed that some of the genre-specific characteristics are related to extra-linguistic factors. This paper focuses on the general and sentence structure of administrative acts, in order to determine whether such acts can be regarded as a distinct genre based on linguistic properties as well.

The administrative acts under consideration have a structure as standardised by the corresponding domain. In $64 \%$ of the administrative acts, background information (reasoning, as well as references to legislation) is syntactically connected to the conclusion. As such, the content is conveyed in the form of declarative speech acts: the issuer of the act describes their own activity (e.g. $X$ issues an order, $X$ decides $+d a$-infinitive), rather than giving out instructions. However, in $26 \%$ of administrative acts there is no syntactic connection between background information and the conclusion, for which reason the conclusion, constructed from $d a$-infinitives, takes the form of instructions. Consequently, the micro-level of administrative acts presents a mixture of descriptive and instructive text types, whereas on the macrolevel the administrative acts here examined represent only the instructive text type.

Although directives are more varied than orders and decisions (e.g. directives include fewer references to the reasons for the issuance of the act and to legislation, and such references are usually syntactically unconnected to the conclusion), the classification of orders, decisions, and directives into distinct administrative acts is primarily based on extra-linguistic (substantial) characteristics. For this reason, on the basis of their use of language they can be regarded as a single genre, a genre of administrative instructions.

Keywords: text type, genre, administrative text, Estonian 